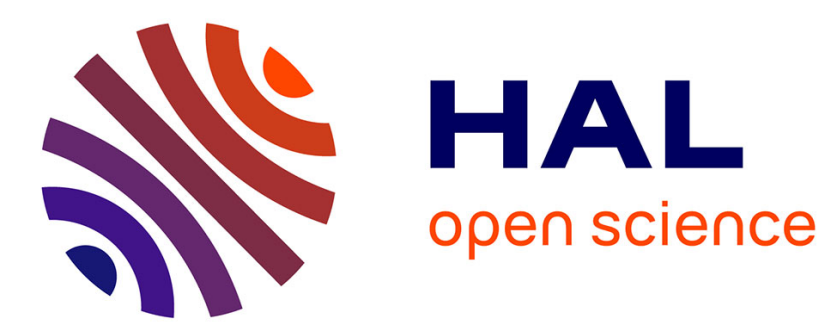

\title{
Management of grazing systems: from decision and biophysical models to principles for action
}

\author{
Michel Duru, Bernard Hubert
}

\section{To cite this version:}

Michel Duru, Bernard Hubert. Management of grazing systems: from decision and biophysical models to principles for action. Agronomie, 2003, 23 (8), pp.689-703. 10.1051/agro:2003051 . hal-00886229

\section{HAL Id: hal-00886229 \\ https://hal.science/hal-00886229}

Submitted on 1 Jan 2003

HAL is a multi-disciplinary open access archive for the deposit and dissemination of scientific research documents, whether they are published or not. The documents may come from teaching and research institutions in France or abroad, or from public or private research centers.
L'archive ouverte pluridisciplinaire HAL, est destinée au dépôt et à la diffusion de documents scientifiques de niveau recherche, publiés ou non, émanant des établissements d'enseignement et de recherche français ou étrangers, des laboratoires publics ou privés. 


\title{
Management of grazing systems: from decision and biophysical models to principles for action
}

\author{
Michel DURU ${ }^{\mathrm{a}}$, Bernard HUBERT ${ }^{\mathrm{b}}$ \\ a INRA Unité d'Agronomie, Chemin de Borde Rouge, BP 27, 31326 Castanet Tolosan, France \\ b INRA Unite d'Écodéveloppement, Domaine Saint-Paul, Site Agroparc, 84914 Avignon Cedex 9, France
}

(Received 5 February 2003; accepted 8 September 2003)

\begin{abstract}
Changes in forage systems taking into account new environmental issues often lead to a reappraisal of the agricultural practices by farmers. These changes also raise new issues about the relevancy of traditional practices of grassland management. We therefore propose an analytical scheme to describe a production plan compatible with land resources (sown or native grasslands). To that end, we present a conceptual model that can be used to design a set of grazing management practices suited to a diversity of specifications. It involves a combination of defoliation and fertiliser practices, allowing different targets to be achieved in terms of herbage yield, composition and grassland biodiversity. Finally, we suggest several management principles underlying these changes in forage systems. These management principles allow the taking of decisions on a monthly to yearly basis, to assess the conformity between farm resources and farmers' objectives, and to coordinate different combinations of herd and land at different periods of the year.
\end{abstract}

grazing / model / decision / extensification / fertilisation

Résumé - Gestion des systèmes de pâturage : des modèles biophysiques et de décision aux principes pour l'action. Les transformations des systèmes fourragers nécessaires à la prise en compte de nouvelles préoccupations (environnement, qualité des produits) se traduisent souvent par une désintensification. Il s'agit d'abord de reconsidérer les entités gérées par les éleveurs. Nous proposons un cadre d'analyse permettant de décliner un projet d'ensemble en objectifs cohérents attachés à chacune de ces entités et compatibles avec les ressources en surfaces, en fourrages cultivés ou spontanés. Ces choix remettent aussi en cause les références habituelles sur la conduite des prairies. C'est pourquoi nous présentons ensuite un modèle conceptuel qui permet de définir des itinéraires techniques adaptés à une diversité de cahiers des charges, d'une part en caractérisant les modes de conduite à partir des pratiques de défoliation et de fertilisation (efficience d'utilisation des ressources, flexibilité), d'autre part en rendant compte de leurs effets sur la production de biomasse et sur la diversité spécifique et fonctionnelle des végétations pâturées. Enfin, nous énonçons quelques principes comme autant de préalables à la création d'outils permettant d'accompagner de telles transformations. Ces principes permettent de raisonner les décisions pluriannuelles (cohérences entre les ressources et les objectifs) et annuelles (coordination entre les différentes "saisons-pratiques").

pâturage / modèle / décision / extensification / fertilisation

\section{INTRODUCTION}

Livestock farming systems are questioned by citizens' concerns about the quality of the environment and of agricultural products. On one hand, consumers put pressure on the authorities through the media and their choice of products; on the other hand, scientists alert the political authorities as to the environmental damage caused by intensive agriculture. Furthermore, authorities are forced to find solutions to overproduction in industrialised countries. They encourage deintensification as a way for farmers to reduce their production and expenses, to adapt to new practices, e.g. organic farming, and to simplify their work [21]. In this paper we describe the potential consequences of these changes on grazing systems, which are called on to de-intensify through reducing animal stocking rates.

The concepts of intensification and extensification apply to several production factors: land, work and capital. In Western Europe land is becoming the least restrictive factor [62]. These concepts are all relative because the evaluation of the de-intensification processes depends on the initial level of intensification. Therefore the goal is less to define a precise limit after which a system is considered as extensive, than to propose an approach for reasoning the coherence between the different decisions to make in a process of de-intensification. This leads to the creation of new concepts and methods to manage the

Communicated by Gérard Guyot (Avignon, France)

\footnotetext{
* Corresponding author: mduru@ $@$ toulouse.inra.fr
} 
resources more in regard of these new aims than in terms of stocking rates or available biomass, as was mainly prescribed in the classical grazing systems' recommendations. For example, de-intensification in grazing systems could involve either decreasing nutrient fertilisers or increasing the contribution of grazing to the animals' diet by enhancing the available surface area, either by starting grazing earlier during periods of slow herbage growth, or by practising deferred grazing to extend the period of grazing when the growth of grass slows down due to climatic factors [82]. In this paper, we focus our purpose on plant resources and not on herd management.

As regards the agro-ecosystem sustainability, the question of de-intensification of grazing systems is raised as soon as there is an imbalance that disrupts the replacement of resources for plants. This may concern the vegetation itself when biodiversity or soil fertility are considered. This first type of situation, observed in most of the grass or range ecosystems throughout the world, generally stems from modalities of herbage off-take (rates and levels) which do not allow the characteristics of the vegetation to be maintained in the medium and long term. Low agro-ecosystem sustainability may also be due to excessive inputs, nitrogen and phosphorus for grass swards or intensive fodder crops such as maize, and pesticides for fodder crops. It is the result of complex phenomena concerning the functioning of ecosystems on a larger organisational scale and over longer periods. This second type of situation is common in Western Europe where the main incentives for de-intensification are ecological and economic [46]. But experiments underway in these countries also show the limits not to be exceeded in countries where, by contrast, there is a trend towards intensification. Thus, the question raised is no longer how to match a one-way improvement model, but to know how to fit locally the most appropriate level in regard to allowed means, production goals and present legislation.

Whatever the situation, the technical solution to such imbalances is not limited to a reduction in inputs or herbage off-take. De-intensification of grazing systems cannot be understood without reference to the livestock system. It must most often be accompanied by a change in feeding systems, in land use (nature of sward used to feed livestock), in the choice of animal genetic material and, more broadly, in the logic in which the organization of technical production systems is grounded. Thus, in countries with marked seasons, where vegetation virtually stops growing for several months because of temperatures or lack of water, the storage and use of forage is essential. In most cases, grass and maize silage are used, but industrial by-products can also be used (beet, sugar cane, rice, etc.). When produced on the farm, this forage is often intensified (nitrogen fertiliser and even irrigation). The use of such energy-rich fodder furthermore requires large protein supplements that are often purchased (e.g. Soya). Grazing animals' food is therefore based essentially on bought inputs - seed, fertiliser, supplements - and thus includes little of the renewable resource, grazed grass. In such breeding systems de-intensification implies a reduction in the use of conserved forage and a consequent increase in grazing, in so far as the cost of production of the former (mainly the cost to yield the crop) depends only a little on the crop mass per ha [11]. In other situations, where surface areas are large enough, herds are led onto reserved areas where standing plants are still available for grazing, such as stockpiled grass. This brief analysis shows that de-intensification cannot be reduced to an increase in the surface area allocated per cow to offset a lower herbage mass resulting from reduced quantities of nitrogen.

Land intensification increases the animal output per hectare, but it also looks like an insurance policy, based on systematic correction of restrictive factors in the environment (mineral elements and water) and high livestock production targets. Yield mechanisation, which most often accompanies land intensification, allows the creation of stored forage stocks which make food systems more reliable by planning for sufficient quantities to compensate for production variability. Deintensification means not necessarily aiming for the production potential allowed by the climate, and therefore always accepting lower livestock performance per hectare or even sometimes per animal.

Planning in grasslands management is done in so far as the aim is to have permanent vegetation in the long run in order to avoid sward deterioration and systematic reseeding. Adaptation of the feeding system to herbage growth variations (variability in the growth rate from year to year, and irregularity within the period) is based on grass sward or plant community properties: respectively, to vary the interval between defoliations to some extent and the possibility of under-grazing the plant community in a particular season without irreversible after-effects on its agronomical value. It supposes to allocate enough surface, leading to lower consumption rates in the course of years whenever herbage growth is better. Thus, the grassland set of questions meets rangeland issues.

In the three following sections of this paper, we detail three main standpoints that have previously been summarised [30]. Section 2 presents concepts and tools to recognise the entities and objects managed by livestock farmers in order to clearly answer - when de-intensification of grazing systems has occurred - the questions: which goals are grazing systems aiming at? And how should they be designed to take into account their relationships with ecological and societal issues? Such analysis ensures that meaningful questions are addressed in research projects concerning grazing systems. It is required to identify specific objectives assigned to each of these entities before determining suitable grazing management. Then, in Section 3 we argue that most often, when grazing management should be reconsidered and diversified, it leads to the study of the underlying processes in plants and their interactions with grazing animals. Finally, in Section 4 we point out that deintensification needs to rethink principles for system designing, planning and steering on different space and time-scales. The last two parts are illustrated by examples chosen from among different livestock systems and different situations of transition towards de-intensification. To illustrate our purpose, the three examples of grazing management that are given in the appendix are mobilised at different places in the paper.

\section{RE-THINKING AND DIVERSIFYING PRODUCTION SYSTEMS IN GRAZING MANAGEMENT}

In this section we present an action-oriented farmer behaviour model to understand how grazing systems work. The 
conception of production systems is actually revised in order to meet new objectives through a diversity in grazing management. Research has to build concepts and methods to make how grazing systems work understandable, so as to produce new scientific knowledge that could be integrated to improve these new grazing management systems, and that is relevant to do it. Revision of such conceptions usually starts with territorial reorganisation, on which farmers base their schedules for the grazing year-schedules that can be adapted, from season to season, depending on climatic events or any other fact which affects their herds' or flocks' lives. To advise and think ahead for these transformations, we need to model the situations in which livestock farmers design their technical systems, and then apply these models to decision-making situations.

\subsection{A model to render decision-making processes intelligible}

To design and manage their production system, livestock farmers must apply their knowledge - of the farm, of the livestock management and the animals' food needs, of the management of the different resources they want to use, of their own skills, etc. - to meet their objectives as regards not only production, but also the constitution of a heritage and social recognition in their professional community and family [18]. Researchers' analysis of the coherence between these different components of production system management requires the construction of a functional representation of the system.

The concept of an "action model" was suggested by Sebillotte and Soler [69] to depict the farmer's decision-making process, seen as part of a permanent recursive, adaptive process in which "the actor readjusts his ultimate goals and his action (on reality) at the same time". In order to do this, he develops a veritable "guide for action" of which a representation can be made through three main points (overall objectives/forecast programme/set of rules), that more or less characterise what we call the "farmer's behaviour model".

Development of an action-oriented farmer's behaviour model requires the construction of a two-tier representation of decision-making processes (discussion with the farmer) and technical operations (field observations) (Fig. 1):

- the farmer's objective and plan: in a livestock production system facing a diversity of goals, overall objectives may be diverse but they always consider animal production to be obtained from a biotechnical programme that achieves its production goals through proper herd feed (including resource renewal) and reproduction management. The programme includes a biological cycle based on a calculated mating schedule which conditions the sequence of events throughout the annual plan, viz. parturition dates, early growth period, marketing forecasts per product type, etc., consistent with grassland states;

- the rules for action that are used to make a combination of elemental decisions constitute the set of rules referred to by the farmer in running his production project. There are general rules connected to the organisation of the production system and circumstantial rules [38]. The former stem from the systems broken down into technical operations independent of the events of the moment; they are vital to project satisfaction. The latter, conversely, are activated as a result

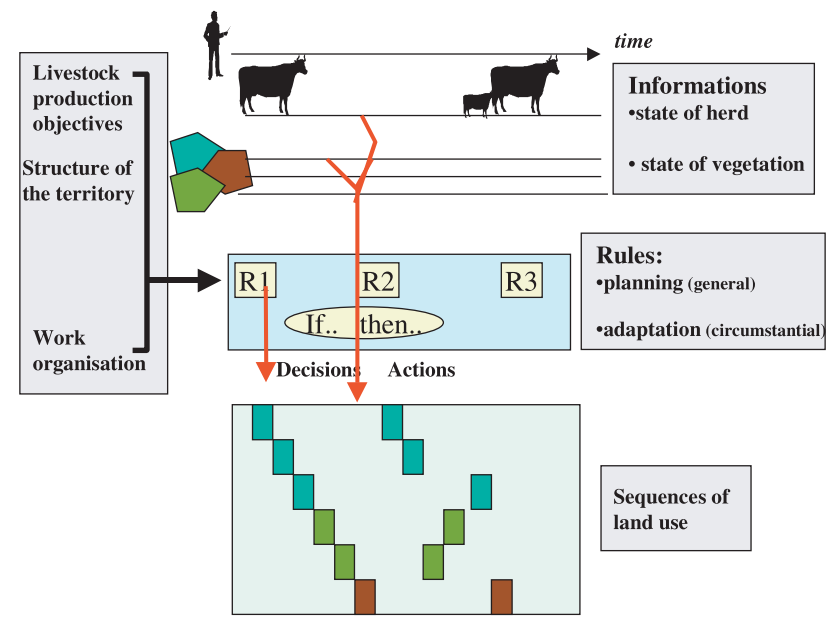

Figure 1. Theoretical scheme of the action model of farmers' behaviour for a grazing system (adapted from [33]).

of information on the state of some elements in the system; they conditionally trigger actions of various kinds that can be accelerated or delayed, depending on the conditions of the moment.

Formalisation of these rules provides insight into the information system that farmers use in a process of self-diagnosis preceding technical operations, and constitutes a unique opportunity for scientist-farmer dialogue. Such a framework was also used by scientists to design their experiment (example 2, [9]). It is therefore essential at this stage to build a representation that is compatible with the scientist's knowledge of livestock and grazing management [19], and to link both knowledge sets. It would then be feasible to articulate integrated biotechnical submodels on livestock husbandry or, for instance, on the effects of management on vegetation characteristics and dynamics (as developed in Sect. 3), for decision-making models on farmers' decisions. New goals leading to de-intensification, such as environmental issues or labour organisation, could change the standards applied to resource management, fertilisation practices, farmland structure, batch duration, etc. Thus, it is possible to identify [38]:

- significant decisions which mark the annual plan management: they may be of various types, e.g. decisions on the herds themselves, assignment of animal groups to certain plots and their removal, the distribution of feed supplement or mowing of grazing plots, etc.;

- goal-oriented phases (subsequent to the significant decisionmaking phase) during which herd management can be considered stable (early lactation, dry cattle, young animal growth, etc.) if measured according to criteria selected for their relevance to identifiable final goals. These phases determine the timing and chronology of the annual plan and the use of farmlands; they support the achievement of the different functions that have to be met to bring off the farmer's aims.

Phases that are closely connected, in pursuit of the same ultimate goal, can be grouped into "sequences" or, in other words, form intermediary elements of the timeframe sequence. Considering land use in terms of "functions" is most meaningful 
from the viewpoint of overall organisation. It is this understanding of how the farmer acts on the biological processes which allows us to reconsider the models which are used to explain sward functioning in order that they fit better with what farmers are actually doing and what they take into consideration, as we develop it in Section 3: which elemental processes are actually questioned?

\subsection{Choosing and combining different grazing management practices on different time-scales}

Configuring a territory for use of heterogeneous pastures by livestock, combining widely diverse types of forage resources, foreseeing the effects of practices on future resources, and planning peak periods are some of the new challenges that these frameworks have to help farmers to meet.

Moreover, to study reorganisations and their implementation, agreement has to be reached on the different time-scales of decisions and actions; in other words, it is necessary to define "a time-based decision structure" as Sheath and Clark [70] suggest:

- on annual and pluri-annual scales, the decisions concern feed profiling, which is the setting of long-term policy, such as the stocking rate, timing of parturition and general stock buying and selling policy. A key indicator of success is the profile of average farm pasture cover throughout the year. The condition score and live-weight of stock should show planned seasonal variation. This strategic planning results in the allocation of areas to a particular use in a given period: a set of animal and plot combinations per period within the year;

- on a seasonal scale, for a given sequence combining a set of animals and plots, grazing plans seek to meet production (sward state) targets, and include decisions on rotation length, daily supplement fed and date to move stock; key indicators are daily lactation, pasture residual sward mass, plant phenology and its sensitivity to grazing.

To fit their goals on different scales, farmers have to combine strategic planning, action plans and daily management. Strategic planning concerns the configuration of the territory of the farm, the areas to reserve for mowing, with or without topping, the spreading of regrowth after mowing, and key grazing dates from turnout to grass until the return to the shed - all in relation to the herds/flocks or batches of animals to feed. A forecast is essential for planning the organisation of means of production, allocating areas for mowing and grazing, and setting production targets. It should go even further than the context of an annual plan, by fitting in with the farm's strategic goals and taking into account their evolution. It consists of a programme for the production year, which has to be completed by adjustments for each period, depending on the development of the annual plan, climatic and economic uncertainties, health hazards, tactical changes or adjustments in production targets and in the organisation of labour. This is a management based on alternatives, regulations, resource substitution, etc. It requires knowledge on how the vegetation reacts to management practices such as fertilisation or defoliation through grazing and how this behaviour panel can be used to plan the grazing agenda.
Girard and Hubert [33] have underlined two main approaches to conceiving decision aids: the first simulates the consequences of different technical or organisational options (in order to investigate the "what happens if?" aspect) and the second is focused on the farmer's project (to understand "what the farmer acts for"). The above proposal - that could easily be modelled by using Knowledge-Based Systems [33] - relates to the "what for?" approach. Our experience of such models enables us to highlight the consistency between the different decisions farmers make with regard to their overall project. They help to make this project understandable to outsiders such as agricultural advisers and scientists. But prioritising decisional components poses problems in connecting the model with the biological components of the system. In Section 3 we suggest shifting from an approach dealing with the productivity and quality of grass, to the management of resource dynamics in terms of changes in grassland states and ways of triggering, now and later, the desired states for satisfactory grazing throughout the year. Such data can then easily be integrated into a "what if" approach, which, usually, carries out simulations to investigate the consequences of different options and helps to choose better ones. But this shift is particularly relevant to a "what for?" approach, which throws the "decision context" as an effective frame to identify which issue is important for the manager and to characterise the objectives he aims to achieve. This new standpoint on the biotechnical components allows thus the forecasting of the efficiency of the system by managing the resource dynamics, stemming from interactions between fertilisation practices and grazing management and their effects on grass growth and sward composition. From this perspective, a decision aid is not to be viewed as supplying generic technological solutions, but as a learning process induced by investigation of alternatives by the farmer and the advisor [78]. Such models are thus used as a mediation tool to support dialogue between farmers and advisors and not as a strict recommendation to be prescribed and followed.

The above representation of livestock farmers' practices through a farmer's behaviour model - is useful for positioning each of the territorial units in the grazing system as a whole and for understanding the reasons for the mode of utilisation and the overtopping constraints. By dividing the land into space frames, territorial units can be identified as a result of observation of farmers' practices: arable plots, paddocks, sectors within land allotments or simply portions of space the herders feel are basic in their land use practices. The usual procedure prioritises plant canopy characteristics while here the main knowledge comes from the analysis of utilisation practices and their effects on plant dynamics (growth, leaves/ stems, species competition, etc.). In the following chapter, we introduce some new concepts to diversify grazing management rules.

\section{SOME TEACHING FROM APPLIED ECOLOGY FOR RETHINKING GRAZING MANAGEMENT}

Studies on grazing have most often been conceived in a perspective of optimisation in order to maximise the efficiency of fertiliser use or herbage utilisation, each of the variables being considered alone. Agronomists have tried above all to optimise 
Table I. Qualitative ranking of the effects of nitrogen rate and grazing pressure on grass sward characteristics and management efficiency, from low (--) to high (++).

\begin{tabular}{lcccc}
\hline Nitrogen application & Grazing pressure* & Net herbage growth & Nitrogen use efficiency & Grazing efficiency \\
\hline Low & Low & -- & ++ & - \\
& High & - & + & - \\
\hline High & Low & + & - & + \\
& High & ++ & - & ++ \\
\hline
\end{tabular}

* over a minimal threshold of residual sward height and interval between two defoliation events which does not reduce herbage growth rate (adapted from [26]).

the use of fertiliser inputs from the point of view of production, by calculating the $\mathrm{N}$ recovery. Establishing a critical mineral content in relation to the quantity of accumulated herbage mass [50] has been used to perform diagnoses independently of sites and years by defining, for example, a quantity of nitrogen necessary to maximise the production of herbage mass, and by taking into account losses that could have been generated by leaching or volatilisation $[39,40]$. On the other hand, researchers working on the grass-animal interface have tried to optimise livestock production by defining appropriate stocking levels [7] and, for some decades, by defining optimum states of sward which allow a high grazing efficiency level (ratio of herbage intake to herbage growth) $[36,60]$. To define optimum management, constructed indicators (herbage nitrogen index and height of sward [3]) have a far more general value than the definition of norms (quantity of nitrogen and stocking rate), which depend on local situations. Yet these references have always been conceived in a perspective of technical optimisation of the use of inputs (herbage mass per fertiliser unit) or of herbage growth (animal output per unit of herbage growth or of standing herbage mass).

Different forms of grazing management must, furthermore, be characterised in terms of flexibility of management and of the means required for their implementation. For de-intensified grazing systems, it is necessary to know the effects of a large range of nitrogen rates and of the modalities of defoliation on the characteristics of the vegetation. Models should be used in this way and not inevitably to determine an optimum management for one criterion. Furthermore, we need integrated models which take into account the properties of regulation of agroecosystems resulting from strong interactions between the structure of the sward, herbage off-take by animals, herbage growth and composition of the herbage mass.

\subsection{Integrated models of the effects of fertilisation and defoliation on the characteristics of vegetation}

\subsubsection{Grazing pressure increases the grazing efficiency but decreases nutrient use efficiency}

By combining the two main action variables, fertilisation and utilisation, it is possible to define diverse management modes whose effects can be evaluated on the net production of herbage mass and its composition, and on the efficiency of the harvesting and use of nutrients (Tab. I). Intensive grassland management allows for high grazing efficiency, at least as long as the value of the residual leaf index does not hinder growth, whereas de-intensification, by reducing either inputs or intensity of use, enhances the nutrient use efficiency. We present below the state of the available knowledge about the biological mechanisms that can be steered by these two levers to manage grazing in different chosen ways.

The proportion of nitrogen application in the form of fertilisers found in the aboveground herbage mass decreases with the increasing quantity applied. The result is an increase in risks of loss by leaching and volatilisation [40]. Furthermore, the use efficiency of mineral elements (production of herbage mass by unit of nitrogen or phosphorus absorbed) increases when the dose applied decreases and when the growth time increases. These variations in efficiency stem from allometric relations between the nitrogen content and the accumulation of herbage mass [50]. The minimum quantity of nitrogen absorbed (kg/ha) that allows maximum growth (t of DM accumulated by ha) differs between species in $\mathrm{C} 3$ and $\mathrm{C} 4$ but hardly varies between species in the same metabolic group: $\mathrm{N}_{\text {uptake }}=\mathrm{a}(\mathrm{W})^{0.68}(\mathrm{a}=48$ for $\mathrm{C} 3$ or 36 for $\mathrm{C} 4)$ [50]. The more favourable the growth conditions (radiation and temperature), the faster this dilution and the higher the quantities of nitrogen needed to obtain a given level will be. This critical quantity allows us to calculate the efficiency variation for a canopy, when $\mathrm{N}$ is non-limiting for growth and when the accumulated herbage mass increases due to longer growth time: $\mathrm{NUE}=\mathrm{W} /$ $48(\mathrm{~W})^{0.68}=20.8(\mathrm{~W})^{0.32}$ for species in C3. The ratio between the quantity of nitrogen absorbed and the reference quantity calculated for the same herbage mass enables us to estimate the nitrogen nutrition level of the sward: $\mathrm{N}_{\text {uptake }} / 48(\mathrm{~W})^{0.68}$. It is linearly correlated with the rate of growth $[5,27]$. Thus, the target of a non-limiting nitrogen nutrition level of the grassland necessarily leads to an accumulation in the soil of unconsumed nitrogen, likely to subsequently be lost. Low grazing frequency and small fertiliser inputs are therefore two factors favouring the efficient use of nutrients.

For a given grassland species, an optimum defoliation regime to maximise grazing efficiency has been defined. When the height is too low, growth is reduced due to a leaf area index that is too low for capturing most of the incident radiation, but beyond this threshold, reducing the intensity of use, either by lengthening the interval between defoliation or grazing, or by increasing the residual height after grazing, results in greater losses from senescence [20]; in other words, reduced grazing efficiency [49] and hence stocking density $[36,60,61]$. This type of farming is also concomitant with a reduction in the quality of the grass offered, either due to lignification of the tissue related to longer growth time, or due to 
a less favourable anatomical composition [83] related to the length of the sheath estimated through the height of the grass [29]. Thus, variations in the intensity of use, either above or below the optimum, reduce grazing efficiency. Reduced nitrogen fertilisation also reduces grazing efficiency in so far as the rate of senescence remains the same whereas the production of herbage mass is reduced.

\subsubsection{Flexibility in grazing management depends on $N$ fertiliser supply related to animal performance and $N$ excretion targets}

Flexibility in grazing management has been defined as the possibility of being able to vary the defoliation interval while keeping given thresholds of offered herbage mass and herbage $\mathrm{N}$ content for animal performances and $\mathrm{N}$ excretion.

The production of grazing animals depends on the quantities ingested and the nutritive value of herbage intake. For homogeneous mono-specific swards, the quantities ingested increase with the intake per bite [65], which is a function of the herbage offered per animal (herbage allowance) or the height of the sward on which it depends and, more precisely, on the proportion of leaf blades [53]. For a given stocking rate, the quantity of grass offered per animal is a function of the available herbage mass. A minimum quantity of blades, depending on the animal species, is required if the quantities ingested on a daily scale are not to be penalised $[63,67]$. The nitrogen content of the vegetation informs on both the crude protein content offered (leaf blades or aboveground herbage mass) and the potential level of $\mathrm{N}$ animal urine excretion. The protein content is lower for nitrogen-free treatments, especially for short re-growth time. The same nitrogen content can therefore be attained soon after defoliation in the case of reduced nitrogen fertilisation, or later, in the case of a higher nitrogen application. A minimum protein content, likely to reduce animal production performance, is reached sooner when nitrogen applications are reduced. A minimum threshold of crude protein content, in relation to the dairy production objective, is required. On the other hand, to limit the nitrogen content of animal excretion, a reduction in the nitrogen content of forage can be obtained either by reducing nitrogen fertilisation or by increasing the time of re-growth. Both alternatives have the same effect on urine excretions [64]. Yet the nutritional con- sequences are different since in the latter case, in addition to the reduced protein content, there is reduced digestibility [22] and quantities of nitrogen absorbed [64]. The comparison of intervals between defoliations with which several criteria can be met when high livestock production performance is required (minimum quantity of blades and minima and maxima nitrogen contents), shows that the reduction of nitrogen application makes it possible to reduce the risk of $\mathrm{N}$ animal excretion. However, it delays the starting date of possible grazing to attain a minimum quantity of blades, and brings forward the closing date of possible use so as not to descend lower than a minimum protein content. The reduction in the level of nitrogen nutrition therefore reduces the interval between two defoliations, compatible with these different constraints, and thus reduces the flexibility of grazing management. However, the range of solutions decreases to a lesser extent when the objective of livestock production performance decreases. Increasing the intervals between two defoliations, without necessarily reducing the $\mathrm{N}$ input, also reduces risks of $\mathrm{N}$ losses from animal excretion, but leads to a loss of flexibility, since it reduces the minimum time between utilisations.

The proposed framework, made up from a set of figures, is meant to help in the choice of consistent $\mathrm{N}$ fertiliser rates to meet both animal and environmental targets while leaving room for flexibility, as illustrated in Table II.

\subsubsection{Biodiversity of natural or semi-natural grasslands depends on the intensity of defoliation and the availability of mineral nutrients}

Apart from its importance as a natural heritage [59], biodiversity can have a functional role in livestock production. For one, specific diversity within a plant community gives it an advantage regarding its use. At a field plot level this may consist of grassland management no longer having the aim only of herbage off-take but also of maintaining or changing the botanical composition [72]. These changes can be brought about by the introduction of new species or regression in the quantities of existing species. Agricultural practices (fertilisation and defoliation) have a direct effect on the survival rates of seedlings of species likely to grow there, on the fertility rates of species already present, and indirectly on competitive relations. On a larger space scale, biodiversity is also a way of

Table II. Assessement of grazing management flexibility for two $\mathrm{N}$ fertiliser treatments (N+, N-). Management flexibility is defined as the difference between late and early dates of a defoliation event (number of days) permitting the meeting of targets for herbage mass (W) and crude protein content (CP); an example adapted from [27].

\begin{tabular}{|c|c|c|}
\hline \multirow[t]{2}{*}{ Sward state thresholds } & $\mathrm{N}+$ & N- \\
\hline & \multicolumn{2}{|c|}{ Number of days of regrowth to reach herbage mass and CP thresholds } \\
\hline minimum lamina herbage mass $\left(1200 \mathrm{~kg} \mathrm{ha}^{-1}\right)^{*}$; date: $\mathrm{Wl}_{\min }$ & 20 & 40 \\
\hline maximum lamina herbage mass $\left(3000 \mathrm{~kg} \mathrm{ha}^{-1}\right)^{*}$; date: $\mathrm{Wl}_{\max }$ & 55 & 70 \\
\hline minimum $\mathrm{CP}$ content $\left(120{\left.\mathrm{~g} 1000 \mathrm{~g}^{-1}\right) \mathrm{t} \text {; date: } \mathrm{CP}_{\min }}\right.$ & 70 & 50 \\
\hline \multirow[t]{3}{*}{ 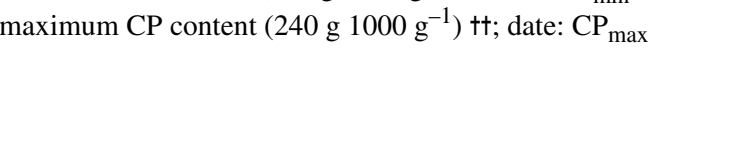 } & 25 & 20 \\
\hline & \multicolumn{2}{|c|}{ Flexibility (days): $\left[\mathrm{Min}\left(\mathrm{Wl}_{\max }, \mathrm{CP}_{\min }\right)-\mathrm{Max}\left(\mathrm{Wl}_{\min }, \mathrm{CP}_{\max }\right)\right]$} \\
\hline & 30 & 10 \\
\hline
\end{tabular}

\footnotetext{
*: from [65]; †: from [23]; tt: from [64].
} 
Table III. A framework to study the effect of management (nutrient, defoliation) on vegetation characteristics for rich-species grasslands, using plant leaf traits: + and - mean respectively, positive and negative relationships.

\begin{tabular}{lccccc}
\hline Leaf traits & \multicolumn{2}{c}{$\begin{array}{c}\text { Plant leaf traits' response when there is an } \\
\text { increase in }\end{array}$} & & Vegetation characteristics & $\begin{array}{c}\text { Main leaf trait which is positively } \\
\text { correlated }\end{array}$ \\
\cline { 2 - 3 } & Nutrient availability & Grazing pressure & & Herbage mass at ceiling yield & Leaf lifespan (5) \\
\cline { 1 - 2 } $\begin{array}{l}\text { Specific leaf area } \\
\text { Leaf lifespan }\end{array}$ & $+(1)$ & $+(2)$ & & Herbage digestibility & Specific leaf area (4) \\
\hline
\end{tabular}

(1): [43]; (2): [81]; (3): [68]; (4): [24]; (5): Cruz et al. (unpublished data).

preserving those species which enable the botanical composition to evolve through the creation of different types of pasture with different characteristics in terms of the production levels of herbage mass and its composition.

Both competition and herbivory can affect plant abundance and distribution [45]. That is why natural grasslands can be classified in relation to the intensity of farming and, more precisely, to the level of fertilisation and the intensity of use (Switzerland: [41]; Massif Central: [51]; French Alps: [42], Pyrenees: [4]). It is therefore the same two factors which govern the characteristics (canopy height, bulk density and leaf stem ratio) of natural grasslands and of mono-specific sward (cf. Sect. 2.1.1). These models allow a rough classification of grazed vegetation and hay meadows, depending on the diversity of species within the pastures [32].

Functional ecology enables us to go from a descriptive approach of the vegetation, based on the identification of species, to an approach based on the morphological or ecophysiological characteristics of the species, in order to group together those having the same function in the ecosystem [79]. Knowing which plant strategies are suited to which combination of factors, it is then possible to deduce the agronomic properties of communities without necessarily referring to the list of species, since plant strategies are independent of the situations (landscape, soil, etc.), unlike species [35].

Intensive natural grasslands have a reduced number of species due to the fierce competition between them, especially for light, except if they are intensively defoliated. It is the species with the best light resource capture abilities that dominate. One of the main traits of these species is both high specific leaf area and leaf area ratio $[8,77]$. By contrast, when the nutrient availability is low, a larger number of species can cohabit, provided they have the capacity to preserve resources (Tab. III). That is why these species develop adaptations such as a longer aboveground nutrient mean residence time ( $\mathrm{N}$ and $\mathrm{P}$ ) in leaves [1]. Species which preserve resources (slow relative growth) have higher lignin and hemicellulose levels [66]. They also have a richer secondary metabolite content. The effects of the defoliation regime on the number of species can also be interpreted by the features of the species. In the case of frequent defoliation, the specific diversity decreases because many species reach the limits of their phenotypic plasticity. This is because these species are no longer able to place their growth zone below the off-take level. The only species that remain are those which develop strategies of avoidance of or tolerance to frequent defoliation [10]. The height of the mature plant can be an indicator of its adaptation to defoliation [80]. On the other hand, when the intensity of use decreases, species with a tissue accumulation strategy develop [32]. The species corresponding to this type of strategy are characterised by longer leaf lifespan and later phenology (Tab. III). When the intensity of herbage use decreases sharply, there is a risk of invasion by so-called undesirable species likely to accomplish their complete demographic cycle (production and dissemination of seeds) and thus to dominate the pasture. This risk is greater when the availability of mineral resources is high. In this case, there is a reduction in the specific species diversity.

When the number of species is small, they generally present a high level of similarity in their plant traits; that is, they can be related to the same functional group [44]. The agronomic characteristics of the pasture can then be deduced from those of the dominant functional group. By contrast, when there is less competition for light, several functional groups can coexist [44]. The level of available mineral resources therefore has an effect on the production of herbage mass and its composition due to the strategies of species facilitated by that habitat. Similarly, the defoliation regime introduces changes in species composition either directly (mortality following meristem intake) or indirectly (change in relative competitive ability), which will result in differences in the dynamics of accumulation of herbage mass during regrowth (when leading to change in average date of flowering or leaf livespan), or even in the mineral needs per unit of herbage growth. In the case of pastures that are exclusively grazed, this phenomenon can result in substantial heterogeneity of the vegetation, mainly in setstocking grazing. Properly adapted under-stocking thus favours several types of vegetation, each with species belonging to a different functional group. This type of result has been obtained in Brazil during long-term experimentation in continuous grazing where the stocking rate is regularly adapted to the available herbage mass [58].

The extent of these dynamics depends a great deal on the botanical potential of the environment (aboveground vegetation and seed bank) [2], but also on the seed vectors (manure, animals, etc.). Each grassland community characterised by a given botanical composition can be linked to an agronomical value to meet a given function (as identified in Sect. 2), in terms of adapted defoliation regime, level of production, and possible herbage off-take. The different types of vegetation thus constitute a range that can be combined in a forage system, as we saw in Section 2. That is why biodiversity plays a functional role on the scale of a small region, by way of the possibilities it affords to move from one type of vegetation to another, and thus to change its use. 


\subsection{Definition of different modes of grazing management}

\subsubsection{Decreasing fertiliser input and defoliation regime: two ways to de-intensify grasslands}

The knowledge presented above enables us to define different forms of grazing management in terms of combinations of levels of fertiliser supply and defoliation regimes (frequency of defoliation and grazing pressure, i.e. number of animals of a specified class per unit weight of herbage) adapted to objectives and to the available resources at farm level (labour, land, etc.).

Starting from a high grazing pressure, this is called "intensive set" management (quasi-synchronism between growth and utilisation); de-intensification may concern only a reduction in the application of nitrogen and other fertilisers (example 2), without changing the species planted and the frequency or the height of defoliation, which nevertheless reduces the grazing efficiency. That is why the increase in surface area must do more than compensate for reduced growth. This type of management necessitates a low residual sward height, short intervals between defoliation or early harvesting of fodder silage. In planted pastures, species with leaves with a short lifespan are well-suited to this type of farming (e.g. perennial rye-grass). In natural or semi-natural grasslands, these species grow better with this mode of farming, and more or less rapidly, depending on the richness of the seed bank and the extent of seed rain. It is important to ensure that changes in agronomic characteristics (digestibility and height) concomitant with changes in the botanical composition remain compatible with the intended use of these grasslands.

When de-intensification also involves a reduction in the period of distribution of stored feed, the grazing season has to be extended (example 1). It is therefore necessary to decrease the grazing frequency. As a result, over a threshold which depends on the leaf livespan, the efficiency of the grazing and of the food value of the grass offered decreases. But these options can remain compatible with the feeding of the herd or flock, especially if they are adopted when the demands of livestock production are smaller. The choice of species with long-life leaves or whose nutritive value declines slowly (white clover) facilitates the implementation of this type of management. In natural grasslands this type of species is favoured by such management (example 3 ). The consequences in terms of intake quantity and quality and sward structure can be quantified to identify whether such an option remains compatible with the livestock production objectives at the time it is adopted. This deferred or lenient grazing management consists of longer intervals between production and use of grass, and to a greater residual height, which makes it particularly flexible. With deferred grazing management it is possible to: (i) guarantee grazing by creating and maintaining a quantity of grass ahead of needs so that the livestock can be fed even in cases of temporarily slower growth - by contrast, in set management it is important to vary the surface area offered by adding or removing paddocks, and (ii) reduce production costs by prolonging the grazing season at the end of winter and during periods when growth declines (early summer or late autumn), by extending the interval between two periods of use, follow- ing the introduction of new fields. However, limits have to be defined for these modalities of defoliation in the cases of natural or semi-natural grasslands, to avoid deterioration of the sward. In cases of considerable under-stocking and when risks exist of introduction of species that are hardly eaten or not at all, set management is necessary to limit the survival of seedlings or young plants during periods when they are still sensitive to grazing, so that deferred management can be practised the rest of the time [54].

Most often, de-intensification combines both a reduction in quantities of fertilisers leading to a decrease in the stocking rate, and changes in the modalities of defoliation, some of them stressing the decrease in the stocking rate more. It is possible to vary modalities of defoliation during the year in the same field (example 1) or, on the contrary, to specialise fields by type of management (example 2).

These types of management differ in terms of resource needs at the farm level. Intensive set management allows high stocking rates and consequently requires less surface area than deferred management. However, large reserves of stored fodder are necessary since the grazing season is shorter. Moreover, this model requires the utmost vigilance and attentiveness to anticipate variations in the growth of grass and mobilise buffer areas, used for cutting or grazing in order to regulate the whole grazing system as developed in Section 2, depending on the state of the grazed pastures and the stored fodder reserves [12]. Paddocks with mixed use must, however, be identified in advance, at the end of winter, although they will be allotted during the spring grazing only [14]. With deferred management, stocking rates are lower due to increased losses, and often to reduced nitrogen application. In those cases vegetation acts as a buffer as regards variations in herbage growth $[25,28]$. The stock of standing herbage, owing to its variations, makes it possible to reduce the effects of fluctuations in herbage growth. These two models are archetypes in so far as intermediate or hybrid models, depending on the time of the year, are frequently observed [13].

\subsubsection{Managing defoliation for its immediate and deferred effects}

Apart from its function of immediate herbage off-take to feed herbivores whose quantitative and qualitative needs vary, grazing also serves to prepare resources for later use. This dual function differs, however, depending on the intensification of the pasture.

For intensified systems, this preparation is intended to create a sward structure favourable to intake in the subsequent grazing period, most often between 1 and 5 weeks following utilisation. Either the grazing is continuous or rotations are short. This preparation is carried out preventively by opting for intense grazing so that grass shafts remain short and thus favourable to quality re-growth [13] and so that herbage rejection is limited. Sward height is an indicator used to decide on variations in the stocking rate or changing of paddock numbers. It applies to the height of the vegetation in continuous grazing [47] or the residual height compared with the height before a rotational grazing [48, 57]. This indicator, which is usually sufficient, has constant values or generally has increasing values during the grazing season. Hay or silage harvest is needed periodically to 
regulate the supply so as to attain these grassland states despite variations in herbage growth. If this regulatory function is not performed, curative mechanical means (cutting ungrazed grass) are usually necessary to maintain an appropriate sward structure in the paddocks.

Following de-intensification, this preparation is no longer based on a single and stable criterion throughout the grazing period. A pasture managed conventionally in early spring may subsequently be managed by deferred grazing from the period of high production to a period of feed shortage (example 1). Hay or silage harvest has not only the function of storing forage resources but also the function of initiating series of regrowth for planned use five to seven weeks later. Moreover, in this logic the interval between the time of the action and the time the effects are expected increases, which requires the manager to have greater foresight. On the other hand, the same precision is not sought in the grassland states.

When de-intensification is on a bigger scale of space, the function of controlling the vegetation can play a preponderant part (example 3). Thus, for natural grasslands grazed by animals with low energy requirement, the aim may also be to control the morphology of a given species or its abundance if it is undesirable. The aim of the grazing system may be to eliminate the spikes in spring by a targeted high stocked grazing period, in order to cut the apexes so as to avoid too much of a decrease in herbage quality or a deterioration in sward structure. It may also be to favour mortality of young shoots of undesirable species, whether herbaceous or woody, at a time when they are palatable, by densely stocking high-risk fields [73]. These aims can have the result, more than in the preceding case, of modifying the rules of batching which are then no longer set exclusively in terms of livestock production objectives. Batching of herds or flocks is a way of organising animal assignment to target plots in relation to their diverse food needs, in order to fulfil the different functions of grazing, as has been developed in Section 2.

Achieving such objectives, with more complex interactions to deal with and such an organisation to steer in space and time, requires renewing the usual frameworks and criteria to manage grazing.

\section{APPROACHES TO CONCEIVING DECISION AID AT FARM LEVEL}

The development of new livestock production systems is an iterative process based partly on observed situations designed by farmers in different situations and formalised knowledge produced by research and extension services, based on prototypes in experimental farms, and partly on more analytical research results and modelling for a few decades [53]. Prototypes aim to experiment with a limited number of scenarios corresponding to different operational logics and are then compared with real situations or evaluated in farmlet experiments. In this part, we only give some principles according to two main management levels (designing and planning on one hand, steering on the other hand) in order to show that new ways for grazing management can be achieved by using new models to produce a diversity of resources from grasslands (see Sect. 3) in respect of farmers' decisional frameworks (see Sect. 2). It is not DSS but a prerequisite to build them.

\subsection{Principles for system design and planning the agricultural year}

Once a herd/flock reproduction management system has been defined, different logics can be described ex ante in terms of rules for land use (type of grasslands, grazing, mowing and fertilisation) and livestock feeding, to draw up grazing and feeding schedules (examples 1, 2 and 3). These schedules are defined by the nature and extent of the planned adjustments to environmental variations: extension of transition periods, planned grazing area and conserved forage provisions [16]. Thus the whole grazing and mowing area is organised in the best way to plan for the year long, including on-course choices to regulate unexpected events, some identified plots being allocated to a range of potential uses [37]. For grazing as such, the nature, order of operations and sequences in time are also specified. The season-practice concept proposed by Bellon et al. [6] enables us to represent these functional grazing entities by integrating both their expected period of use and the grazing modalities (number and type of animals, supplemental feeding, if any, and duration of grazing period), adapted to the type of resource required at that time of the year and to the expected effect on the dynamics of these resources and their respective subsequent use. The annual grazing plan can thus be represented as a planned sequence of season-practices based on the simultaneous or combined use of several paddocks by different batches of animals formed by the farmer, through generic models built from a top-down standpoint with the use of Knowledge-based systems [34]. This representation, which shows the farmer's scheduling of the immediate and delayed effects of defoliation produced each time animals graze in a paddock, as developed in Section 3.2.2, for set or deferred management, could be implemented using mathematical tools for making DSS based on a combination of a biophysical model and a decisional model from a bottom-up point of view [16]. In situations of de-intensification, this planning is particularly important since it conditions the success of the grazing year which no longer depends only - as in the case of more intensive systems - on the immediate adjustment of the growth of plant biomass and animal uptake, but also on the control of defoliation regimes (examples 2 and 3 ).

The different de-intensification options involve various difficulties of implementation (Tab. IV). They could be taken into account when building DSS, by designing relevant decision rules [17]. In the intensive logic, grazing management is hardly flexible when grazed grass is the only feed resource. It is more so in de-intensification and is facilitated by rotational grazing in so far as it is possible to vary the intervals between two uses, without necessarily creating refusal [56]. The spatial heterogeneity of vegetation is greater and production levels more variable from year to year, since they are not corrected by high nitrogen applications. The organisation must fully incorporate these difficulties rather than trying to avoid or ignore them, so that it can take advantage of them to enhance flexibility and reliability (example 3 ).

Applying Knowledge-based systems on a regional scale, a study by Girard and Hubert [33] on farmers' strategies and 
Table IV. Some key differences in de-intensified grazing systems compared with intensive ones. After [56, 71, 76].

\begin{tabular}{|c|c|c|}
\hline Issues & Intensive system & De-intensified system \\
\hline Input & $\begin{array}{l}\text { High inputs to overcome limitations } \\
\text { of natural soil fertility }\end{array}$ & Low inputs and outputs per ha \\
\hline $\begin{array}{l}\text { Grazing and winter forage } \\
\text { conservation }\end{array}$ & $\begin{array}{l}\text { Limited grazing period through } \\
\text { conserved feed }\end{array}$ & Extended grazing period \\
\hline $\begin{array}{l}\text { Adaptation to grass growth } \\
\text { variation }\end{array}$ & Conserved feed & $\begin{array}{l}\text { Low stocking rate; both pasture plants and grazing animals have to } \\
\text { adjust to the effects of any imbalance in forage supply and demand }\end{array}$ \\
\hline $\begin{array}{l}\text { Information availability/functional } \\
\text { complexity }\end{array}$ & $\begin{array}{l}\text { Relatively good, both on ecological } \\
\text { processes and resource base }\end{array}$ & Poor, leading to flat optimising surfaces; scenario \\
\hline Grazing flexibility & Low & High, prefer rotational grazing to continuous stocking \\
\hline Spatial heterogeneity & Between management units & Within management units \\
\hline Temporal variability & Reasonable annual replicability & Wider year to year variability \\
\hline
\end{tabular}

Table V. Classifying attitudes to uncertainty in sheep farming in Southern France [from 33].

\begin{tabular}{lll}
\hline Attitudes to uncertainty & Designing a livestock farming system & Steering a livestock farming system \\
\hline Avoid hazards & $\begin{array}{l}\text { - crops to secure resources in periods with unavoidable hazards } \\
\text { - allocate sufficient areas for growing winter feed supplies } \\
\text { to control indoor feeding }\end{array}$ & \\
\hline Rule out hazards & - oversize the farm territory & - set absolute decision rules \\
\hline $\begin{array}{l}\text { Diversify to reduce the } \\
\text { effects of hazards }\end{array}$ & $\begin{array}{l}\text { - decentralise livestock equipment to increase the number } \\
\text { of grazing sectors } \\
\text { - grow forage resources within the rangeland to create a mosaic } \\
\text { of fields }\end{array}$ & $\begin{array}{l}\text { - divide flock into batches, reserving the best } \\
\text { resources for part of flock only }\end{array}$ \\
\hline React to effects of hazards & & $\begin{array}{l}\text { - divide flock into batches to seize opportunities } \\
\text { - supplement the flock to complete pasture feeding }\end{array}$
\end{tabular}

responses to uncertainty in sheep farming systems in a valley in Southern France confirms the subjective nature of the notion of "risk". In a nutshell: farmers set up strategies to cope with risk and in so doing they display contrasting attitudes to uncertainty resulting from risk (climatic, in a mountainous Mediterranean area, and economic, in a very competitive market). The scale of farmers' preferences, their ways of doing things and, finally, the representations they have of their environment - almost from one to another - vary considerably. The information processed, the indicators used, and the perception of seasonal time patterns and important events are not the same throughout this category of farmers, as summarised in Table V. Thus, sheep farms, which are largely divided between intensified systems, de-intensified and never-intensified ones (from the top to the bottom of the table) illustrates that, among these categories, those which are the most intensified give greater importance to designing than steering; inversely, de-intensification increases the need for steering without giving up designing.

System designing and planning is an iterative process requiring, alternatively, a framework within which decisions are made and actions carried out (Sect. 2), and biotechnical models (Sect. 3).

\subsection{Consequences of decision support with or without formal DSS}

It is in respect of decision aid that the grazing management models presented above can be applied. Considering that choices have already been made, certain decisions taken, resources and feeding methods decided on, and types of forage resources graded, it is therefore necessary, for a period of the year and a set of paddocks, to define rules concerning dates and conditions of intervention, e.g. date of turnout to grass after wintering (example 1), duration of the transition, number of paddocks allocated and evolution during the period, as well as the rules governing the sequencing of interventions (e.g. intervals between two uses). Rules for adjustments to variations in the environment (hazards) or in biological systems make it possible to modify the nature, intensity or order of interventions.

Thus, in management of the system, the role of the information system is critical in regard to decision-making: decisions are taken according to the knowledge available to the farmer. It consists of providing access to the relevant data concerning the biophysical system and the external environment. What is relevant is highly subjective and is actually part of the decisionmaking behaviour adopted. Decision support systems aim to 
improve knowledge of the functioning of the system and its environment; obviously it triggers directly the farmer's information system. Note that this information system has two functions:

- interpreting and storing some decision-relevant data about the biophysical system and external environment, and communicating the results to the decision system;

- monitoring some expected events in the biophysical system or external environment and notifying their occurrence to the decision system that uses them as decision-making temporal landmarks.

De-intensification issues thus help to enhance the livestock farmers' information system through new knowledge, that is, new indicators to observe and new means to guarantee control of defoliation regimes as developed in Section 3. Deferred grazing management, for example, is not based on the same functional signals of the grazing system as traditional rotational grazing. The view of defoliation levels and proportions of leaves and sheaths, the perception of heterogeneity of uptake in a paddock (example 3), and the evolution of grassland flora (example 2) will not be interpreted in the same way and will not lead to the same corrective actions in terms of fertilisation, mowing or changes in the modalities of grazing. It is thus new technical references that are expected and have to be produced in situ, either on the basis of experiments or on that of observations of livestock farms, followed by researchdevelopment in the context of either research programmes or technical-economic networks, as the current examples show.

Providing models and producing strictly biotechnical references does not suffice to deal with the problems posed in types of organisation that differ and to support decisions that are relevant. A similar modelling effort is needed to understand these organisations which form the framework in which decisions are made and actions carried out $[15,17]$. They therefore require differentiated advice and interventions from researchers and agricultural advisors, leading to a new generation of DSS, less prescriptive and more interactive.

\section{CONCLUSION: AN APPROACH TO FUNCTIONAL INTEGRITY}

The movement towards de-intensification is often seen in terms of more sustainable agricultural systems. The available knowledge does not prove that such systems are more sustainable, especially since the movement is still recent and few reliable data exist to evaluate changes that can be analysed only in the long term. It is, moreover, difficult to establish the range of evaluation criteria in the economic, ecological and social domains, if only because the effects and consequences of farming systems mostly need to be measured at levels of organisation other than only those of the farms concerned. This would require complex analytical tools and efficient models, most of which are currently a subject of controversy among the scientists who use them. We can nevertheless contribute towards current conceptual and methodological reflection and debate on the subject of approaches to sustainable agriculture, as follows.
For instance, one of the difficulties is to stay within the limits where this change in the intensity of use is compatible with livestock production performance targets and does not affect the sustainability of resources for plants as well as plant resources for animals. De-intensification implies sufficient land resources. Less fertiliser application, when it results in a reduction in the herbage mass produced, or a less intense defoliation regime, always imply the need for a larger surface area if the number of animals is constant. But an increase in the required surface area will depend to a large extent on the maintenance or not of the duration of the grazing period. We find here two options that we developed above: when the proportion of stored forage is reduced, the required surface area for grazing increases more than if the change concerned only fertilisation, since the feeding modalities have not changed. This condition is not possible in all regions, because access to land is limited or too expensive, nor in all production systems. Furthermore, additional constraints concern the spatial organisation of grazed fields. For example, with dairy animals, which are milked, grazed areas must be close to the shed. When deintensification requires changes to the grassland species sown (or the presence of different dominant species in permanent grasslands), certain conditions have to be met regarding soil and landscape. Likewise, the extension of grazing periods can cause smaller areas to be reserved for animals with smaller needs and for use in a period when risks of damage to the grassland are low, and can therefore cause paddock use allocation to be revised.

Thomson [76], considering the varieties of sustainability in livestock farming, identified two different ways of using this concept, taking into account that it is more difficult to separate fact and values with respect to sustainability than in other domains of scientific research:

- the notion of resource sufficiency is based on the assessment of a practice by measuring the rate at which resources are being consumed and then multiplying that rate by the timeframe over which the practice is to be sustained. It directs attention to potential sources of total resource scarcity, taking into account future generation needs and potential substitutions between resources. These last two points are very controversial, from the standpoint of scientific data as well as ethics;

- the idea of functional integrity presupposes an account of a system having crucial interactions between elements reproduced over time in a manner or at a rate that depends upon previous system states. Thus, it looks at weak links in a system's ability to reproduce its essential elements. The main questions are how to find the correct dimensions for the relevant system (including time steps) and whether human activities are part of the system.

Unlike most research on grazing, involved in evaluating resources through carrying capacities or in modelling resource management rules, our proposal is part of the functional integrity approach, focused on interaction between the grazing herd and pasture dynamics and its management as the relevant system, assessed at the farmland level. For us the functioning of the grazing system is the key element in sustainability of the production system on which the farmer's project is based. The critical interaction, upon which the ability of the system to fit 
new issues - i.e. its sustainability - relies, relates to the management of grazing and fertilisation, some of the plots having distinct use goals, and having to be steered in a flexible way in order to be grazed or mowed according to a given year's economic and climatic conditions. These interactions put at stake the farmer's ability to meet a range of sward heights, relying on a range of species with different leaf characteristics at different stages of growth. The fertilisation practices and the frequency and duration of grazing are the two key levers according to a given land configuration and some options in animal production.

Thus, although we do not take into account the local social system, human activities, i.e. herd (reproduction planning, making batches and marketing) and resource (grazing planning, balance between mowing and grazing, and fertilisation) management practices are definitely part of the system. The originality of our approach is based on the focus on characterisation of an efficient grazing system, and not only on grazing efficiency at the plot level. It is broader in scope, including issues related to environment, labour or economics on larger scales, such as the farm and its surrounding landscape. We think that from this standpoint the functional integrity approach highlights the sustainability of the system at a higher level than what we identified as its core, the grazing system. This amply illustrates how, in this field, new trends induce the need for new decision support systems and not only a revision of strictly agronomic issues. In this meaning, knowledge produced in several situations does not fit a universal value; only arguments and principles become general.

\section{APPENDIX}

\section{Examples of implementation of de-intensification}

The examples come from three experiments: one conducted on dairy farms in Brittany (prototypes of forage systems based on herd monitoring); the second on suckled ewes in the Massif Central; and, lastly, a stocking experimental system in Brazil.

Example 1: De-intensification by increasing grazing period length: prototypes of forage systems on dairy farms (Brittany, West of France, from [74])

Like in many livestock-producing regions, feeding systems in Brittany are characterised by their diversity. Different "menus" have been defined, based on livestock-producing networks. Five models for grazing dairy cows have thus been proposed after observation in the field [74]. Depending on the expected herbage yield and the grazing surface accessible per cow, prototypes are proposed, characterised globally by the number of grazing days per year. Each of these models also specifies elements of decision-making for key dates: turnout to grass, night and day grazing, closing and opening of the silo and end of grazing. Calving is in autumn so that milk production is lowest when growth slows down in summer. Similar results are aimed for from an economic point of view.

We summarise here the decision-making logics defined for the two extreme strategies: "maize all year round: M" and "all grass: $H$ ". The target is a grazing contribution of $25 \%$ and $60 \%$ of the basic ration, respectively. To achieve that percentage, it is necessary to have a grazeable area of 0.20 and 0.70 ha per cow, respectively. The former strategy is reserved for farms with a high dairy production quota per ha. The share and the management of stored forage is different in the two strategies. In $\mathrm{M}$, maize silage is given in unlimited quantities throughout the year, except in spring. In $\mathrm{H}$, the proportion of stored forage (grass silage) is limited to $2 \mathrm{t} \mathrm{DM}$ per head. Climatic variations are offset by the distribution of maize in $\mathrm{M}$, whereas in $\mathrm{H}$ their effects are reduced by the large surface area allocated to grazing. In $M$ grazed pastures are covered primarily with English rye-grass while in $\mathrm{H}$ there is a white clover mixture. Lastly, nitrogen fertilisation can be as much as $250 \mathrm{~kg}$ in $\mathrm{M}$ while in $\mathrm{H}$ it is limited to liquid manure and possibly to $50 \mathrm{~kg}$ of mineral nitrogen. Grazing areas required in $\mathrm{H}$ are larger if fertilisation is reduced.

Consequently, grazing practices differ. For example, in $\mathrm{H}$ turnout to grass is one month earlier. This change is possible because the allocated area is more than three times bigger. Given the early turnout to grass in $\mathrm{H}$, wide variations in grazing time per day are acceptable. The first grazing cycle in $\mathrm{H}$ ends in late March, approximately one month earlier than in M. Provision is made for hay in grazed fields, if necessary. The residual height after grazing rises from $4 \mathrm{~cm}$ (early spring) to $6 \mathrm{~cm}$ (summer) in H. It is about $1 \mathrm{~cm}$ higher in M. It is possible to reduce the residual sward height in $\mathrm{H}$ to slow down growth in the case of an excess of herbage. In summer the silage ration increases to compensate for the reduced herbage growth rate in $\mathrm{M}$, while in $\mathrm{H}$ stocks of standing herbage constitute summer feed whenever possible. This strategy requires a stock of standing herbage on 1 July equivalent to between 25 and 50 days' grazing. The target age of aftermaths is roughly 50 days for a rye-grass/white clover mixture. The indicator proposed to decide whether to add or remove paddocks is primarily the grass height measured in a paddock or the level of all the paddocks in the grazed area $[25,28]$.

Example 2: De-intensification by increasing the surface area and reducing the stocking rate: prototypes of forage systems in suckled ewe farming (mountain area, centre of France, from $[9,52,75])$

Faced with the prospect of expanding farms in grassland areas, trial systems have been set up to conceive variations in livestock management and surface areas, so that new areas can be included whereas flock sizes stay the same. In comparison with a pilot system (T), an enlarged system (A) was designed. The aim was to maintain livestock production performance and economic results, but also to avoid deterioration of the vegetation in this system of lower stocking rates. These two models were designed by researchers, based on their technical knowledge and on observations on farms, and tested experimentally.

Advantage was taken of the reduction in the stocking rate, from $1.2(\mathrm{~T})$ to $0.85 \mathrm{UGB} / \mathrm{ha}(\mathrm{A})$, to reduce inputs of fertilisers and concentrates. Livestock production and economic performance targets were similar in both systems. They were maintained de facto despite a reduction of close to $30 \%$ in the consumption of concentrated feed and of $50 \%$ in forage production costs [75]. 
Below we mention some of the changes effected in decision-making logic. In system $\mathrm{T}$, grass silage and nitrogen fertilisation (roughly $100 \mathrm{~kg} / \mathrm{ha}$ ) allowed for a high stocking rate. In system A, stocks were hay-based and grazing was given priority (on average $+22 \%$ ). In A, breeding management was revised so as to have a class of animals with low needs in early spring and thus to reduce the survival rate of young bushes by immediately implementing a high stocking rate. Reduced quality of available herbage resulting from the reduced stocking rate was also avoided in the lamb fattening period by timely mowing of the pastures to be used for that purpose.

\section{Example 3: De-intensification by maintaining and devel- oping heterogeneity of grassland vegetation: South Brazil $[55,58]$}

This case concerns large-scale cattle farms. Cattle graze natural unfertilised grasslands continuously throughout the year, despite substantial variations in herbage growth. High stocking rates tend to deteriorate these ecosystems, causing high-productivity species to be replaced by low-productivity ones, and an increase in soil cover by creeping species. As a consequence of less soil cover there is an increase in superficial leaking, leading to erosion. On the other hand, excessively low stocking rates produce high herbage patches with a dominance of cespitous graminae of low nutritional value, as well as bushes and other undesirable species mainly from the genera Baccharis and Eryngeum.

Four grazing management systems based on offered herbage $(4,8,12$ and $16 \mathrm{~kg}$ of herbage dry matter per $100 \mathrm{~kg}$ liveweight) were compared. The maximum herbage dry matter production and animal live-weight gain occurred with the $12 \%$ treatment [58].

The four per cent treatment corresponds to excessively high grazing pressure, leading to low radiation capture and high population with almost no grass. The greater the forage availability, the better the harvest and forage selection by the grazing animal, leading to two types of patch: one with palatable species eaten over the summer (short sward), and the other composed of less palatable species, mainly although not exclusively eaten though the winter. As seen below, these species have the ability to accumulate tissues with low senescence rates through the long leaf lifespan and stem. In these grazing systems, the three main decisions are the animal reproductive schedule, the stocking rate in terms of herbage allowance per animal live-weight, and the size of the paddock.

\section{REFERENCES}

[1] Aerts R., Van der Peijil M.J., A simple model to explain the dominance of low-productive perennials in nutrient-poor habitats, Oikos 66 (1993) 144-147.

[2] Alexandre D.Y., Dynamique de la régénération naturelle en forêt dense de Côte d'Ivoire, Stratégies écologiques des arbres de la voûte et potentiels floristiques, Etudes et thèses, ORSTOM (1989).

[3] Armstrong R.H., Robertson E., Hunter E.A., The effect of sward height and its direction of change on the herbage intake, diet selection and performance of weaned lambs grazing ryegrass swards, Grass For. Sci. 50 (1995) 389-398.
[4] Balent G., Construction of a reference frame for studying changes in species composition in pastures: the example of an old-field succession, Opt. Méd., Ed: CIHEAM, Sér. A, Séminaires 15 (1991) 73-81.

[5] Bélanger G., Gastal F., Lemaire G., Growth analysis of a tall fescue sward fertilized with different rates of nitrogen, Crop Sci. 32 (1992) 1371-1376.

[6] Bellon S., Girard N., Guérin G., Caractériser les saisons pratiques pour comprendre l'organisation d'une campagne de pâturage, Fourrages 158 (1999) 115-132.

[7] Béranger C., Increasing production efficiency in plant animal system, Kyoto, XVth International Grassland Congress, 1985, pp. 24-31.

[8] Berendse F., Elberse W.T., Geerts R.H., Competition and nitrogen loss from plants in grassland ecosystems, Ecology 73 (1992) $46-53$.

[9] Brelurut A., Louault F., Benoît M., Tournare H., Thériez M., de Montard F., Liénard G., Dedieu B., Laignel G., Adaptation de l'élevage ovin allaitant à une diminution du chargement. Exemple en moyenne montagne, Ann. Zootech. 47 (1998) 483-490.

[10] Briske D.D., Strategies of plant survival in grazed systems: a functionnal interpretation, in: The ecology and management of grazing systems, edited by Hodgson J. and Illius, A.W. CAB International, 1996, pp. 37-68.

[11] Clark D.A., Jans F., High forage use in sustainable dairy farms, in: Journet M., Grenet E., Farce M.H., Thériez M., Demarquilly C. (Eds.), Recent developments in the nutrition of herbivores, Proc. of the IVth Int. Symp. on the nutrition of herbivores, INRA Editions, Versailles, France, 1995, pp. 497-526.

[12] Coléno F.C., Le pâturage des troupeaux laitiers en question : contribution d'une analyse des décisions des éleveurs, Fourrages 157 (1999) 63-76.

[13] Coleno F.C., Duru M., Gestion de production en système d'élevage utilisateurs d'herbe : une approche par atelier, Étud. Rech. Syst. Agraires Dév. 31 (1998) 45-61.

[14] Coléno F.C., Duru M., A model to find and test decision rules for turnout date and grazing area allocation for a dairy cow system in spring, Agric. Syst. 61 (1999) 151-164.

[15] Coléno F.C., Duru M., Soler L.G., A simulation model of a dairy forage system to evaluate feeding management strategies with spring rotational grazing, Grass For. Sci. 57 (2002) 312-321.

[16] Cros M.J., Duru M., Garcia F., Martin-Clouaire R., A biophysical dairy farm model to evaluate rotational grazing management strategies, Agronomie 23 (2003) 105-122.

[17] Cros M.J., Duru M., Garcia F., Martin-Clouaire R., Simulating management strategies: the rotational grazing example, Agric. Syst. (in press).

[18] Darré J.P., La parole et la technique. L'univers de pensée des éleveurs du Ternois, L'Harmattan, Paris, 1985.

[19] Darré J.P., Hubert B., Les raisons d'un éleveur sont notre raison de coopérer, in: Raisons et pratiques. Dialogue avec un éleveur ovin, Études Rurales 131-132 (1993) 109-115.

[20] Davies A., The regrowth of grass swards, in: Jones M.B., Lazenby A. (Eds.), The Grass Crop, London: Chapman and Hall, 1988, pp. 85-117.

[21] Dedieu B., Chabanet G., Josien E., Bécherel F., Organisation du pâturage et situations contraignantes en travail : démarche d'étude et exemples en élevage bovin viande, Fourrages 149 (1997) 21-36.

[22] Deinum B., Dirven J.G., The effect of temperature on the digestibility of grasses. An analysis, For. Res. 3 (1970) 1-17.

[23] Delaby L., Peyraud J.L., Effet d'une réduction simultanée de la fertilisation azotée et du chargement sur les performances des vaches laitières et la valorisation du pâturage, Ann. Zootech. 47 (1998) 17-39. 
[24] Duru M., Leaf and stem in vitro digestibility for grasses and dicotyledons of meadow plant communities in spring, J. Sci. Food Agric. 74 (1997)175-185

[25] Duru M., Le volume d'herbe disponible par vache : un indicateur synthétique pour évaluer et conduire un pâturage tournant, Prod. Anim. 13 (2000) 325-336.

[26] Duru M., Delaby L., Plant nitrogen status allowing to optimize herbage composition and intake and to minimise nitrogen excretion: an assessment of grazing management flexibility for dairy cows, Grass For. Sci. (2003) in press.

[27] Duru M., Ducrocq H., Tirilly V., Modeling growth of cocksfoo (Dactylis glomerata L.) and tall fescue (Festuca arundinacea Shreb.) at the end of spring in relation to herbage nitrogen status, J. Plant Nutr. 18 (1995) 203-347.

[28] Duru M., Ducrocq H., Bossuet L., Decision rules based on herbage volume to manage a rotational grazing system in spring. Case of dairy cows and ewes, J. Range Manage. 53 (1999) 395-402.

[29] Duru M., Feuillerac E., Ducrocq H., In vitro digestibility response of cocksfoot (Dactylis glomerata L.) to growth and defoliation: a simple model, J. Agric. Sci. 133 (1999) 379-388.

[30] Duru M., Hubert B., De-intensification of grasslands: current state and trends, in: Gomide J., Mattos W., da Silva S. (Eds.), Proc. of the XIX Int. Grassland Congress, Sao Pedro, Bresil, pp. 985-986.

[31] Duru M., Hazard L., Jeangros B., Mosimann E., Fonctionnement de la prairie pâturée : structure du couvert et biodiversité, Fourrages 166 (2001) 165-188.

[32] Duru M., Balent G., Gibon A., Magda D., Theau J.P., Cruz P., Jouany C., Fonctionnement et dynamique des prairies permanentes. Exemple des Pyrénées centrales, Fourrages 153 (1998) 97-113.

[33] Girard N., Hubert B., A conceptual framework to identify a diversity of farmer's strategies and responses to uncertainty in sheep farming systems of southern France in Livestock Farming Systems: More than Food Production, in: Sorensen J.T. (Ed.), 4th International Livestock Farming Systems Symposium, Foulum (Denmark), 22-23 Aug. 1996, EAAP Publ. No. 89, Wageningen Pers (Wageningen), 1997, pp. 60-66.

[34] Girard N., Hubert B., Modelling expert knowledge with knowledge based systems to design decision aid support. The examplification of a knowledge-based model on grazing management, Agric. Syst. 59 (1999) 123-144.

[35] Grime J.P., Plant strategies, vegetation processes and ecosystem properties, J. Wiley, 2001, $417 \mathrm{p}$

[36] Hodgson J., The significance of sward characteristics in the management of temperate sown pasture, Kyoto, XVth International Grassland Congress (1985).

[37] Hubert B., Pastoralisme et territoire. Modélisation des pratiques d'utilisation, Cah. Agric. 3 (1994) 9-22.

[38] Hubert B., Girard N., Bellon S., Lasseur J., Les systèmes d'élevage ovin préalpins. Derrière les pratiques, des conceptions modélisables, in: Pratiques d'élevage extensif. Identifier, modéliser, évaluer, Étud. Rech. Syst. Agraires Dév. 27 (1993) 351-385.

[39] Jarvis O.R., Wilkins J., Pain B.F., Opportunities for reducing the environmental impact of dairy farming managements: a systems approach, Grass For. Sci. 51 (1996) 21-31.

[40] Jarvis S.C., Nitrogen management and sustainability, in: Cherney J.H., Cherney D.J.R. (Eds.), Grass for dairy cattle, CABI Publishing, 1998, pp. 161-192.

[41] Jeangros B., Berther V., Scehovic J., Plantes herbacées dicotylédones : une contribution à la biodiversité des prairies permanentes, Rev. Suisse Agric. 26 (1994) 151-154; 163-166.

[42] Jeannin B., Fleury F., Dorioz M., Typologie régionale des prairies permanentes fondée sur leur aptitude à remplir des fonctions. ITypologie des prairies d'altitude des Alpes du Nord : méthode et réalisation, Fourrages 128 (1991) 379-398.
[43] Knops J.M.H., Reinhart K., Specific leaf area along a nitrogen fertilization gradient, Am. Midland Natur. 144 (2000) 265-272.

[44] Lavorel S., McIntyre S., Plant functional types: is the real world too complex?, in: People and Rangelands: Building the Future, Proceedings of the VI Int. Rangeland Congress, Townsville, Australia, July 19-23, Vol. 2, 1999, pp. 905-911.

[45] Lavorel S., Garnier E., Predicting changes in community composition and ecosystem functioning from plant traits: revisting the Holy Grail, Funct. Ecol. 16 (2002) (in press).

[46] Leaver J.D., Milk production from grazed temperate grassland, J. Dairy Res. 52 (1985) 313-344.

[47] Le Du Y.L.P., Baker R.D., Newberry R.D., Herbage intake and milk production by grazing dairy cows. A. Effects of grazing severity under continuous stocking, Grass For. Sci. 36 (1981) 307318.

[48] Le Du Y.L.P., Combellas J., Hodgson J., Herbage intake and milk production by grazing dairy cows. 2 . The effects of level of winter feeding and daily herbage allowance, Grass For. Sci. 36 (1979) 249-260.

[49] Lemaire G., Les flux de tissus foliaires au sein des peuplements prairiaux. Eléments pour une conduite raisonnée du pâturage, Fourrages 159 (1999) 203-222.

[50] Lemaire G., Gastal F., N uptake and distribution in plant canopies In diagnosis of the nitrogen status in the crops, Springer Verlag, 1997, pp. 3-44.

[51] Loiseau P., Louault F., L'Homme G., Gestion des écosystèmes pâturés en situations extensives : apports de l'écologie fonctionnelle et perspectives de recherche en moyenne montagne humide, Ann. Zootech. 47 (1998) 395-403.

[52] Louault F., de Montard F., Brelerut A., Thériez M., Pailleux J.Y., Benoît M., Liénard G., Extensification en élevage bovin par agrandissement des surfaces. Adaptation de la gestion des prairies, Fourrages 154 (1998) 217-237.

[53] McCown R.L., Hochman Z., Carberry P.S., Probing the enigma of the Decision Support System for farmers: learning from experience and from theory, Agric. Syst. 74 (2002) 179-220.

[54] Magda D., Theau J.P., Duru M., Defining management rules for grasslands using demographic characteristics of weeds, Weed Res. (2003) in press.

[55] Maraschin G.E., Moojen E.L., Escosteguy C.M.D., Correa F.L., Apezteguia E.S., Boldrini I.J., Riboldi J., Native pasture, forage on offer and animal response, in: Proc. of XVIIIth Int. G C, Canada, Paper 288 (1997).

[56] Maxwell T.J., Milne J.A., Role of herbivores in sustainable land production systems. Principles and practice. Some of the issues, in Journet M., Grenet E., Farce M.H., Thériez M., Demarquilly C. (Eds.), INRA, 1995, pp. 17-31

[57] Mayne C.S., Newberry R.D., Woodcock S.C., Wilkins R.J., Effect of grazing severity on grass utilization and milk production of rotationally grazed dairy cows, Grass For. Sci. (1987) 59-72.

[58] Nasbinger C., de Moares A., Maraschin G.E., Campos in Southern Brazil in grassland ecophysiology and grazing ecology, in: Lemaire G., Hodgson J., de Moares A., de F. Carvalho P.C., Nabinger C. (Eds.), 1999, pp. 355-376.

[59] Nösberger J., Rodriguez M., Increasing biodiversity through management, XVI EGF meeting (1998).

[60] Parsons A.J., The effect of season and managment on the grass growth of grass sward, in: The grass crop, 1988, pp. 129-178.

[61] Parsons A.J., Chapman D.F., Principles of grass growth and pasture utilization, in: Grass for dairy cattle, CABI Publishing, 1998, pp. 282-309.

[62] Peeters A., Extensification of grasslands in Europe, in: Proc. of XVIIIth Int. G C, Canada, Paper 15, 1993. 
[63] Penning P.D., Parsons A.J., Orr R.J., Hooper G.E., Intake and behaviour response by sheep to changes in sward characteristics under rotational grazing, Grass For. Sci. 49 (1996) 476-486.

[64] Peyraud J.L., Fertilisation azotée des prairies et nutrition des vaches laitières. Conséquences sur le rejet d'azote, Prod. Anim. 13 (2000) 61-72.

[65] Peyraud J.L., Gonzalez A., Relationships between production, supplementation and intake in grazing dairy cows, in: Soegaard et al. (Eds.), Grassland farming. Grassland in Europe, Vol. 5, 2000, pp. 269-282.

[66] Poorter H., Bergkotte M., Chemical composition of 24 wild species differing in relative growth rate, Plant Cell Environ. 15 (1992) 221-229.

[67] Prache S., Peyraud J.L., Préhensibilité de l'herbe pâturée, Prod. Anim. 10 (1997) 377-390.

[68] Ryser P., The importance of tissue density for growth and life span of leaves and roots: a comparison of five ecollogically contrasting grasses, Funct. Ecol. 10 (1996) 717-723.

[69] Sébillotte M., Soler L.G., Les processus de décision des agriculteurs. Première partie : acquis et questions vives, in: Brossier J., Vissac B., Le Moigne J.L. (Eds.), Modélisation systémique et système agraire, INRA Publications, 1990, pp. 93-101.

[70] Sheath G.W., Clark D.A., Management of grazing systems: temperate pastures, in: The ecology and management of grazing systems, edited by Hodgson J. and Illius, A.W. CAB International, 1996, pp. 301-324.

[71] Stafford Smith M., Management of rangelands: paradigms at their limits. 1., in: The ecology and management of grazing systems, edited by Hodgson J. and Illius, A.W. CAB International, 1996, pp. 325-358.

[72] Stuth J.W., Hamilton W.T., Conner J.C., Sheehy D.P., Decision support systems in the transfer of grassland technology, in: Proc. of XVIIIth Int. G C, Canada, pp. 749-757.

[73] Theau J.P., Magda D., Duru M., Coleno F.C., Towards sustainable livestock systems in constrained areas: a method to assess the effect of grassland management on production and the dynamics of undesirable species. Grassland Farming. Balancing environ- mental and economic demands. Grassland Science Europe, EGF 2000, 22-25 May, Aälborg, Denmark: (EGF), pp. 81-83, 2000.

[74] Thébault M., Dequin A., Follet D., Grasset M., Roger P., Dossier : 5 menus pour vaches laitières au pâturage : le pâturage au quotidien, du plan d'alimentation à la conduite de l'herbe + Guide pratique de l'éleveur, 1998.

[75] Thériez M., Brelerut A., Pailleux J.Y., Benoît M., Liénard G., Louault F., de Montard F., Extensification en élevage ovin viande par agrandissement des surfaces fourragères. Résultats zootechniques et économiques de 5 ans d'expérience dans le Massif Central Nord, INRA Prod. Anim. 10 (1997) 141-152.

[76] Thompson P.B., The varieties of sustainability in livestock farming, in: Livestock Farming Systems. More than food production, Proc. 4th Int. Symp. on Livestock Farming Systems, Aug. 1996, Foulum (Denmark), in: Sorensen J.T. (Ed.), EAAP Publication No. 89, Wageningen Pers, Wageningen, 1997, pp. 5-15.

[77] Van Der Werf A., Visser A.J., Schieving F., Lambers H., Evidence for optimal partitionning of biomass and nitrogen at a range of nitrogen availibilities for a fast-growing and slow-growing species, Funct. Ecol. 7 (1993) 63-74.

[78] Walker D.H., Decision support learning and rural resource management, Agric. Syst. 73 (2002) 113-127.

[79] Weiher E., Van der Werf A., Thompson K., Roderick M., Garnier E., Eriksson O., Challenging Theophrastus: A common core list of plant traits for functional ecology, J. Veg. Sci. 10 (1999) 609-620.

[80] Westoby M., A leaf-height-seed (LHS) plant ecology strategy scheme, Plant and Soil 199 (1998) 213-227.

[81] Westoby M., The LHS strategy sheme in relation to grazing and fire, Proc. VIth Int. Rangeland Cong., Townsville, Australia, Vol. 2, 1999, pp. 893-896.

[82] Wilkins R.J., Optimisation of grass utilisation in high rainfall temperate conditions, in: Journet M., Grenet E., Farce M.H., Thériez M., Demarquilly C. (Eds.), INRA, 1995, pp. 363-380.

[83] Wilson J.R., Variation of leaf characteristics with level of insertion on a grass tiller. I. Development rate, chemical composition and dry matter digestibility, Aust. J. Agric. Res. 27 (1976) 343-354. 